8. Food intake of pigs offered meal containing either 0.5 or $1 \cdot 0 \%$ copper sulphate rapidly fell to a very low level and the pigs failed to gain weight. All pigs resumed satisfactory growth and food intake immediately the copper supplement was reduced to $0.1 \%$, or omitted from the diet.

9. The results obtained are discussed in relation to the known toxic effects of feeding of very high amounts of copper to sheep and cattle.

\title{
REFERENCES
}

Andrus, S. (1955). Analyst, 80, $5 \mathrm{I} 4$.

Barber, R. S., Braude, R. \& Mitchell, K. G. (1955). Brit. J. Nutr. 9, 378.

Barber, R. S., Braude, R., Mitchell, K. G. \& Cassidy, J. (1955). Chem. E Ind. p. 601.

Barber, R. S., Braude, R., Mitchell, K. G., Rook, J. A. F. \& Rowell, J. G. (1956). Proc. Nutr. Soc. $\mathbf{r}_{5}$, ix.

Bowler, R. J., Braude, R., Campbell, R. C., Craddock-Turnbull, J. N., Fieldsend, H. F., Griffiths, E. K., Lucas, I. A. M., Mitchell, K. G., Nickalls, N. J. D. \& Taylor, J. H. (r955). Brit. F. Nutr. 9, 358.

Braude, R., Coates, M. E., Davies, M. K., Harrison, G. F. \& Mitchell, K. G. (1955). Brit. F. Nutr. 9, 363.

Cartwright, G. E. (1950). In A Symposium on Copper Metabolism. Baltimore: Johns Hopkins Press.

Clegg, F. G. (1956). Vet. Rec. 68, 332.

Eggleton, W. G. E. (r940). Biochem. F. 34, 99 I.

Monier-Williams, G. W. (1949). Trace Elements in Food. London: Chapman and Hall Ltd.

Ogilvie, D. D. (1954). Vet. Rec. 66, 279.

Taylor, J. H. \& Harrington, G. (1955). Nature, Lond., 175, 643.

\section{The specific dynamic action of food and the satiety mechanism}

\author{
By R. PASSMORE AND FIONA J. RITCHIE \\ Department of Physiology, University of Edinburgh
}

(Received 26 September 1956)

Food intake is controlled by two centres in the hypothalamus, a 'feeding centre' which promotes feeding and 'a satiety centre' which inhibits it. Several workers have contributed to the anatomical discovery of these centres (for review see Brobeck, 1956). The nature of the sensory stimuli to which these centres respond is, however, still uncertain. Brobeck (1948) has developed the hypothesis that increased heat production is an important signal to the satiety centre. In brief, he postulates that 'animals eat to keep warm and stop eating to prevent hyperthermia'. He is, however, careful to point out that changes in heat production may be only one of several stimuli to which the centres react. Indeed, Brobeck (1956) draws an analogy between the feeding centres and the respiratory centres, which are well known to be sensitive to several different types of stimulus. He (Brobeck, 1948; Strominger \& Brobeck, r953) has given two elegant demonstrations, using rats, which are entirely consistent with his 
hypothesis that changes in heat production are an important physiological stimulus to the feeding centres. The only evidence in man that he quotes are the experiments of Booth \& Strang (1936), who reported that after a meal of beef-steak, eaten in quantities sufficient to produce satiety, skin temperatures of the palm of the hand and sole of the foot rose in normal persons up to $2^{\circ}$ after $I \mathrm{~h}$. In obese persons there was either no rise or a very small one. Booth $\&$ Strang suggested that this rise in skin temperature might be part of a satiety mechanism.

We have repeated the experiments of Booth \& Strang and also investigated the extra heat production (the specific dynamic action, S.D.A.) after a standard meal in two human subjects under different, standardized conditions of satiety. Our results are consistent with Brobeck's hypothesis that variations in heat production could be part of a mechanism producing satiety, but they also indicate that it is unlikely that these changes are the only factors responsible.

\section{EXPERIMENTS TO MEASURE THE RISE IN BODY TEMPERATURE AFTER A MEAL}

Experimental. Three men acted as subjects for eight experiments. Two of them were thin. As a test meal, beef-steak was given in amounts sufficient to produce satiety. The meal was taken at about midday, the subjects having fasted since the previous evening. Temperatures were measured by six thermistors, sensitive to about $0.05^{\circ}$, situated on the skin, over the abdomen, chest, arm, thigh, palm of the hand and sole of the foot, and by one thermistor in the rectum. The experiments were performed in an ordinary laboratory, in which room temperature was kept at $25 \pm I^{\circ}$ by switching on or off electric radiators. The subjects were screened from draughts and sources of heat. They wore light summer clothes.

Results. In seven of the eight experiments, rectal temperature rose by a maximum of $0.2^{\circ}$ between $\mathrm{I}$ and $2 \mathrm{~h}$ after the meal and in the other, it remained unchanged. Changes of skin temperature, including those of the hand and foot, were quite inconsistent, some rising and some falling in each experiment. In general, the rises in skin temperature were greater and more numerous than the falls, but the mean changes in the eight experiments reflect the general inconsistency. These were: rectum $+0.1^{\circ}$, palm of the hand $+0.5^{\circ}$, sole of the foot $-0.2^{\circ}$, abdomen $+0.2^{\circ}$, chest $+0.2^{\circ}$, arm $-0.1^{\circ}$, thigh $-0.1^{\circ}$. However, in each experiment, there was a well-marked s.D.A. effect of the meal, as measured by indirect calorimetry, as further discussed on p. 83 .

Discussion. We concluded that the rise in body temperature in man associated with satiety was too small to be accurately measured without rigorous control of the environment and of the subject. Accuracy and consistency could probably only be obtained if the subject were enclosed in a very small room, in which temperature, air movement, humidity and radiant heat were controlled with precision and all the records were made by observers outside the room. The necessary experimental procedure would be both difficult and expensive and quite unsuitable for large-scale investigation of variations of the satiety mechanisms under different conditions and in thin and obese subjects. 
Our results are thus at variance with those of Booth \& Strang (1936) who reported a consistent and regular rise in the skin temperature over the palm of the hand and sole of the foot up to $2^{\circ}$ in $\mathrm{I} h$ in normal persons. Unfortunately, Booth $\&$ Strang give very few details of their results in individual subjects, in striking contrast to Strang's classic paper on S.D.A. (Strang \& McCluggage, I93I) in which full details on all subjects of a most rigorous procedure are recorded. They found that in the ist hour after a meal of beef-steak sufficient to produce satiety, the increase in metabolic rate was on the average 1o Cal./ $\mathrm{h}$ (calculated by interpolation from their graphs). In a man weighing $70 \mathrm{~kg}$ and with a specific heat of 0.83 (Burton \& Edholm, 1955), this increase would produce a rise in average body temperature of $0.17^{\circ}$, if there was no increase in heat loss. In fact, of course, the average rise of body temperature i $h$ after a meal would be much less, as some increase in rates of heat loss would be expected and all the excess heat would not be stored. The extra heat in the body would not be expected to be evenly distributed. But it would seem unlikely that a rise of less than $0.17^{\circ}$ of mean body temperature would lead to a consistent rise of the order of $2^{\circ}$ over the palms of the hands and the soles of the feet. It might be so, but seems improbable. To measure accurately the small changes of body temperature after a meal, a most exacting technique would appear to be necessary.

\section{EXPERIMENTS ON THE SPECIFIC DYNAMIC ACTION OF A STANDARD MEAL IN RELATION TO SATIETY}

After concluding that measurement of body temperature was an unsatisfactory technique for studying the effects of heat production on satiety, we investigated rates of change of heat production as measured by indirect calorimetry. The classical work on S.D.A. is concerned primarily with the size of the effect and its relation to the nature of the meal. If Brobeck's hypothesis is correct, then the time relations are important, for satiety arises immediately after a meal. The classical papers on S.D.A. (see Benedict $\&$ Carpenter, I9I8; Strang \& McCluggage, I93I) only record values at a considerable interval (usually $\mathrm{I} \mathrm{h}$ ) after the end of a meal. If the heat produced by S.D.A. is an important part of the stimulus responsible for the cessation of eating and the sensation of satiety, then both the time relations and the absolute amount of the S.D.A. should be suitably correlated with satiety.

Design. To test this concept, the following experiment was devised and carried out on two persons. Preliminary observations showed that a midday meal of 675 Cal. was sufficient to satisfy needs and not to cause discomfort, when ordinary dietary habits were followed. The same meal was then given at midday $(a)$ when the subjects had previously starved for a period of between 16 and $22 \mathrm{~h}$ and $(b)$ when the subjects had deliberately eaten to excess at the previous evening meal, at breakfast that morning and had also taken a mid-morning snack. The s.D.A. of the meal under the two different circumstances was measured.

Subjects. The subjects were P. W. F. (female, age 46 , weight $65 \mathrm{~kg}$, height $175 \mathrm{~cm}$ ) and R. P. (male, age 46 , weight $65 \mathrm{~kg}$, height $183 \mathrm{~cm}$ ). Each sat in a comfortable arm-chair for $\mathrm{I} h$ before and after the consumption of the meal, which was at about 
midday. Room temperature was maintained at about $\mathrm{x} 8^{\circ}$. They wore normal indoor clothing.

As a test meal, the substance Complan was used. This is a compound food based on milk powder enriched with protein and other nutrients, prepared by Glaxo Laboratories Ltd. Preliminary experiments indicated that $150 \mathrm{~g}$ satisfied requirements for a midday meal on a normal day. This amount was given to both subjects in all experiments. It supplied $675 \mathrm{Cal}$. and $46 \mathrm{~g}$ protein. The Complan was made up with $400-500 \mathrm{ml}$. of water, roughly at body temperature. This meal has the advantage that it can be consumed rapidly with a minimum of muscular movement, which might disturb metabolism. It was usually consumed in between 2 and $4 \mathrm{~min}$, nearer the former when the subject was starved and the latter when stuffed.

The S.D.A. was measured by indirect calorimetry. Expired air was collected in a Douglas bag for three $5 \mathrm{~min}$ periods immediately before the meal and for six consecutive $5 \mathrm{~min}$ periods with $5 \mathrm{~min}$ intervals between each, beginning at $2 \mathrm{~min}$ after the end of feeding. Gas analyses were done in duplicate with the Haldane apparatus.

Results. Table I and Fig. I show the mean heat-production rate for three experiments on each subject, when starved and when stuffed. Results from individual experiments showed only minor differences in levels of heat production, but no change in the time relations of the response. When the subject was previously starved, the meal did not produce satiety and the subject remained hungry and as soon as the experiment was ended went out and readily ate a normal lunch. When the subject was previously stuffed, the meal was less easily taken; a feeling of satiety with minor discomfort always arose immediately.

Discussion. The results show that in all experiments there was a well-marked s.D.A. which reached a maximum $30-40 \mathrm{~min}$ after the meal. An s.D.A. effect was usually demonstrable in the first measurement immediately after the meal and was always well established in the second sample taken around ${ }_{5} 5 \mathrm{~min}$ after the meal. There was indeed, as Fig. I shows, no demonstrable latent period for the effect. In fifteen other experiments carried out on three other subjects in which meat was used as the test meal, there was also no evidence of any latent period. This is an important point, for it establishes the possibility of S.D.A. being part of a satiety mechanism. If the S.D.A. had a significant latent period, it would be difficult to see how it could promote the normal feeling of satiety, which is associated with the cessation of eating. As regards the size of the S.D.A. and the relation to satiety, there was a difference in the two subjects. In P. W. F., there was an almost clear separation between the values when satiated and when not. When the metabolic rate was below $x \cdot 2 \mathrm{Cal} . / \mathrm{min}$, she was hungry; when it was above, she was not. In this subject it would appear that the S.D.A. could well be a major factor determining satiety and the cessation of eating. In R. P., the situation was very different and the two curves are not widely separated. Even when he was previously starved, the meal, although inadequate and not satisfying hunger caused a S.D.A. approaching that when satiated. There was no clear-cut association with satiety. In R. P. it would seem that S.D.A. by itself could not cause satiety, though it might well contribute to it. 
Table I. Changes in energy expenditure (Cal./min) after a standard meal $(675 \mathrm{Cal}$, $46 \mathrm{~g}$ protein), showing the specific dynamic effect

(Each figure is the mean of three experiments)

\begin{tabular}{|c|c|c|c|c|c|c|c|c|}
\hline \multirow[b]{2}{*}{ Subject } & \multirow[b]{2}{*}{ Condition } & \multirow[b]{2}{*}{$\begin{array}{l}\text { Before } \\
\text { meal }\end{array}$} & \multicolumn{6}{|c|}{ After meal } \\
\hline & & & $5 \mathrm{~min}$ & I $5 \mathrm{~min}$ & $25 \mathrm{~min}$ & $35 \mathrm{~min}$ & $45 \mathrm{~min}$ & $55 \mathrm{~min}$ \\
\hline \multirow[t]{2}{*}{ R. P. } & $\begin{array}{l}\text { Previously starved. } \\
\text { No satiety }\end{array}$ & $1 \cdot 04$ & $I \cdot I I$ & $1 \cdot 26$ & $x \cdot 33$ & $I \cdot 36$ & $\mathrm{I} \cdot 42$ & $I \cdot 3 I$ \\
\hline & $\begin{array}{l}\text { Previously overfed. } \\
\text { Satiety }\end{array}$ & $I \cdot 20$ & $x \cdot 26$ & $I \cdot 37$ & $1 \cdot 40$ & $I \cdot 51$ & $I \cdot 5 I$ & $I \cdot 5 I$ \\
\hline \multirow[t]{2}{*}{ P. W. F. } & $\begin{array}{l}\text { Previously starved. } \\
\text { No satiety }\end{array}$ & $1 \cdot 02$ & 1.07 & 1.08 & $I \cdot I 5$ & $1 \cdot 20$ & $I \cdot I 8$ & $I \cdot I 8$ \\
\hline & $\begin{array}{l}\text { Previously overfed. } \\
\text { Satiety }\end{array}$ & $I \cdot I 9$ & $I \cdot 26$ & I.35 & $r \cdot 38$ & $1 \cdot 42$ & $\mathrm{I} \cdot 37$ & $1 \cdot 32$ \\
\hline
\end{tabular}

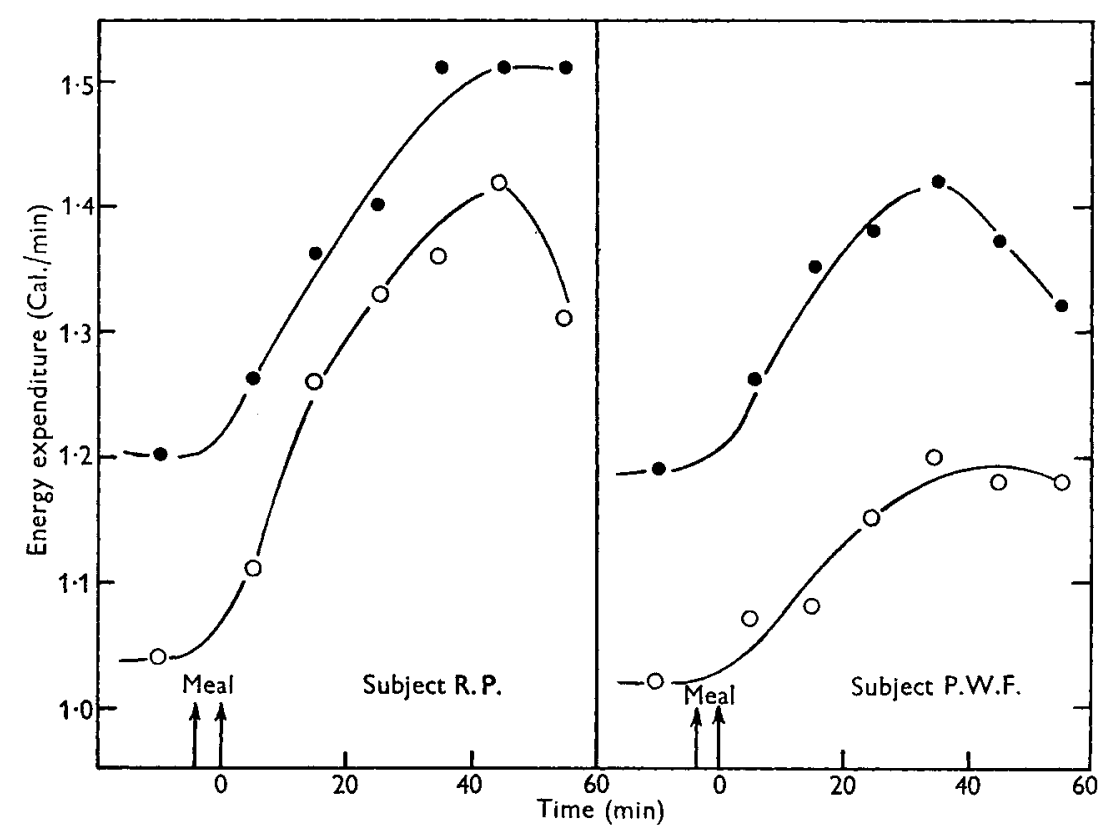

Fig. I. Changes in energy expenditure in two subjects after standard meal. The rise in the curves shows the specific dynamic effect of the meal. $O$, when the subjects were previously starved and the meal did not satisfy appetite; $\bullet$, when the subjects had previously overfed and were satiated.

\section{DISCUSSION}

These experiments lend general support to Brobeck's (1948) hypothesis that changes in heat production could be an important stimulus to the feeding and satiety centres in the hypothalamus. They also indicate that there may be important differences between individuals and that other factors must be involved.

Changes of body temperature are so small that the technical difficulties in accurately measuring them are very great. It would appear impractical to use them to study variations in different individuals and the effects of day-to-day changes in feeding 
habits. On the other hand, the S.D.A. can be determined accurately and much more readily with standard laboratory equipment.

The demonstration that S.D.A. has apparently no latent period in man revives old controversies as to its nature. Over 50 years ago there was great argument in the German literature on this point. Rubner (1902) maintained that the S.D.A. was caused by products of digestion after absorption. On the other hand, Magnus-Levy ( 1894 , I907) postulated that it was due, in part at least, to the work of the digestive glands (Verdaunngarbeit). The clear-cut demonstration by the Mayo Clinic workers (Wilhelmj, Bollman \& Mann, 1928) that intravenously injected amino-acids cause a well-marked S.D.A. in eviscerated dogs, but that this effect is lost after removal of the liver, showed that Rubner was right. However, they did not show that Magnus-Levy was wrong. Perhaps both were right. Nevertheless, almost all text-books of physiology and nutrition refer only to Rubner's view. Any effect of a meal mediated by aminoacids acting on the liver should have a latent period, which could be easily demonstrated. Amino-acids may well be responsible for maintaining the S.D.A. action for several hours after eating. It is unlikely that they can be responsible for initiating an S.D.A. immediately after eating. Verdaungsarbeit is a factor which appears to have been improperly dismissed. It would repay further study.

Brobeck's (1956) analogy between the hypothalamic feeding centres and the medullary respiratory centres is apt. Respiratory physiologists are concerned with the possibility that changes in heat production, brought about by exercise, for example, may change the sensitivity of the respiratory centres to chemical or nervous stimuli. Our experiments are quite compatible with a similar change in the sensitivity of the feeding centre to chemical and nervous stimuli, brought about by heat. In elucidating this problem, it would be desirable to know where the extra heat resulting from the food is generated and whether the stimulus is carried directly to the central nervous system through a rise in blood temperature or through specific localized thermoreceptors.

\section{SUMMARY}

1. Energy exchange in man during the rst hour after a meal has been investigated. A rise in rectal temperature and a probable rise in average skin temperature have been demonstrated, but these were so small as to make quantitative assessment very difficult.

2. Oxygen consumption increased immediately after a meal and the specific dynamic action of food appears to have no latent period.

3. The results are consistent with Brobeck's (1948) hypothesis that increased heat production is an important part of the satiety mechanism.

4. Other factors besides S.D.A. must also contribute to the satiety mechanism and individual variations are important.

We wish to thank Dr P. W. Fleming and Dr T. S. Lee for acting as subjects and Mr D. S. Shirling for much technical assistance. We are grateful to the Medical Research Council for a personal grant to F. J. R. and an expense grant. 
REFERENCES

Benedict, F. G. \& Carpenter, T. M. (1918). Publ. Carneg. Instn, no. 26 r.

Booth, G. \& Strang, J. M. (1936). Arch intern. Med. 57, 533.

Brobeck, J. R. (1948). Yale f. Biol. Med. 20, 545.

Brobeck, J. R. (1956). Int. physiol. Congr. xx. Brussels, p. 133.

Burton, A. C. \& Edholm, O. G. (I955). Man in a Cold Environment. London: Edward Arnold.

Magnus-Levy, A. (1894). Pflüg. Arch. ges. Physiol. 55, г.

Magnus-Levy, A. (1907). In Metabolism and Practical Medicine, p. 208. [C. von Norden, editor.] English translation. London: W. Heinemann.

Rubner, M. (1902). Quoted by Magnus-Levy (1907).

Strang, J. M. \& McCluggage, H. B. (1931). Amer. F. med. Sci. 182, 49.

Strominger, J. L. \& Brobeck, J. R. (1953). Yale Y. Biol. Med. 25, 383 .

Wilhelmj, C. M., Bollman, J. L. \& Mann, F. C. (r928). Amer. F. Physiol. 87, 497.

\title{
The energy expenditure and food intake of middle-aged Glasgow housewives and their adult daughters
}

\author{
By J. V. G. A. DURNIN, ELAINE C. BLAKE AND J. M. BROCKWAY \\ Institute of Physiology, University of Glasgow
}

(Received 8 October I956)

During recent years there has been a very considerable increase in the available information on energy expenditure in relation to activity. Measurements have been made on individuals of differing ways of life in several countries. Yet few studies have attempted to cover the whole $24 \mathrm{~h}$ period, as opposed to estimates covering the working time only. The scarcity of such studies is probably mainly due to their administrative difficulty and their cost. From this point of view, soldiers present fewer problems than a comparable group of civilians; there have been several excellent field studies on energy intake and expenditure, especially by the U.S., British, Canadian and Australian Armies. Some of these reports, and similar ones in other countries, are published for a restricted circulation, but examples of a few generally available are those by Sargent, Sargent, Johnson \& Stolpe (1954, 1955), Edholm, Fletcher, Widdowson \& McCance (1955), Consolazio, Pollack, Crowley \& Goldstein (1956) and by Buskirk, Kreider, Brebbia, Morana, Daniels, Welch, Mann, Insull \& Friedemann ( 956 ). However, information about civilians is so limited that the Committees on Calorie Requirements of the Food and Agriculture Organization (FAO) of the United Nations have had great difficulty in formulating their recommendations, especially when dealing with calorie allowances for women and with the appropriate decreases in caloric allowances for adults in relation to advancing age. Though some limited observations have been made on the effect of age on the food intake of men, there are few similar data for women. The estimates of calorie requirements and the decrement for age, where women are concerned, have perforce been largely based on guesswork and on the relatively few dietary studies reported. 